\title{
Trends for the Future of Education Programs for Professional Development
}

\author{
María Soledad Ramírez-Montoya ${ }^{1, *}$, Lucy Andrade-Vargas ${ }^{2}$, Diana Rivera-Rogel ${ }^{2}$ and May Portuguez-Castro ${ }^{3}(\mathbb{D}$ \\ 1 School of Humanities and Education, Tecnologico de Monterrey, Monterrey 64849, Mexico \\ 2 Faculty of Social Sciences, Education and Humanities, Universidad Técnica Particular de Loja, \\ Loja 1101608, Ecuador; ldandrade@utpl.edu.ec (L.A.-V.); derivera@utpl.edu.ec (D.R.-R.) \\ 3 Institute for the Future of Education, Tecnologico de Monterrey, Monterrey 64849, Mexico; \\ may.portuguez@tec.mx \\ * Correspondence: solramirez@tec.mx
}

Citation: Ramírez-Montoya, M.S.; Andrade-Vargas, L.; Rivera-Rogel, D.; Portuguez-Castro, M. Trends for the Future of Education Programs for Professional Development. Sustainability 2021, 13, 7244. https:// doi.org/10.3390/su13137244

Academic Editors:

Ebba Ossiannilsson and Aras Bozkurt

Received: 5 April 2021

Accepted: 13 May 2021

Published: 29 June 2021

Publisher's Note: MDPI stays neutral with regard to jurisdictional claims in published maps and institutional affiliations.

Copyright: (c) 2021 by the authors. Licensee MDPI, Basel, Switzerland. This article is an open access article distributed under the terms and conditions of the Creative Commons Attribution (CC BY) license (https:// creativecommons.org/licenses/by/ $4.0 /)$.

\begin{abstract}
Scientific and technological developments bring new requirements for university education and, particularly, the training of education professionals. There is a regular need to update curricula to integrate market trends and educational approaches. It is necessary to know future trends in education and teaching programs. Our research in a higher education institution in Ecuador focused on providing perspectives on the future of educational programs by analyzing trends in educational programs' designs, students and professors' needs for innovative education. We used the descriptive/exploratory case study method, employing quantitative surveys and qualitative interviews, focus groups and benchmarking as instruments. The surveys were applied to 337 current students, 384 potential students and 313 graduates of Educational Sciences. We conducted interviews with 20 experts from Mexico, Spain, Colombia and Ecuador. We held focus groups with 32 education professionals, including rectors, principals, educational specialists and primary, secondary and university teachers. Benchmarking was used in our analysis of ten universities. The results focused on five elements that were units of analysis (1) characteristics of education programs, (2) student requirements, (3) required educational modalities, (4) trends in education and (5) future of education programs. The data and results may be of interest to decision-makers, academicians, researchers, students and citizens interested in professional education and other disciplinary areas.
\end{abstract}

Keywords: education; trends; educational innovation; higher education; case study; educational demand; innovative programs

\section{Introduction}

The evolution of education brings with it future trends in education such as the presence of artificial intelligences flexibility of the education offer, the transformation of the teaching role and the digitalization of the educational environment, which make us reflect on the past and be aware of the present. Covid-19 marked a before-and-after point in education where it was necessary to evaluate teachers and students' roles in the teaching-learning process [1]. A good teacher must locate, organize and adapt resources for various contexts [2], as technological advances have opened up significant teaching and learning opportunities [3]. For this reason, a growing number of teachers are integrating digital tools and social networks in their teaching [4]. Trends in education should be closely linked to education for sustainable development, where the academic community works with the sensitivity to solve real and critical problems, as well as perspective to work collaboratively in a sustainable future, through the formation of citizens committed to the local and global environment.

Educational-training trends link process changes to results. According to the Horizon Report [5], the six trends in education for the next five years are the culture of innovation, deep learning, changes in learning assessment, redesign of learning spaces and 
hybrid and collaborative learning. In addition, Talbert, Hofkens and Wang [6] propose student-centered learning to enhance student engagement. Furthermore, online learning is mentioned for its flexibility [7] and priority due to Covid-19 [8]. Undoubtedly, the future of education will not be the same. Teachers will have to share the stage with artificial intelligence systems and hybrid teaching methodologies.

Therefore, both teachers and students must have digital competencies. Digital competency is one of the eight core competencies of the European Reference Framework for lifelong learning [9]. These competencies enable young people to leverage content from an academic perspective [10], i.e., to reflect on developing knowledge [11]. Hence, the competency-based approach in education is still valid [12]. Undoubtedly, the impact of information communication technologies (ICTs) in the academic environment will mark its future; therefore, teachers and students must be trained in their proper use, consumption and prosumption.

\subsection{Current Status of Education Programs in Ecuador}

Ecuador's universities offer 286 third-level education programs and 33 postgraduate programs related to education. The specialty in which nursery schoolteachers are trained was among the ten most sought in the second semester of 2017 and the first semester of 2018. In the first postulation of the second cycle of 2018, 3.7\% of applicants (5994) were males opting for Early Childhood Education and 3.1\% (5020) for Primary Education [13]. Since 2015, teacher training has been in crisis because most of the existing training offerings were closed [14]. In response, the National University of Education-UNAE and the "I Want to Be a Teacher" program were created [15]. In Ecuador, education combines formal and informal learning, permanent, ubiquitous and adaptive, beyond traditional learning environments [16]. The education is learner-centered and employs technologies to follow the learner's progress, providing real-time actionable data for adaptations that need to be made [17]. This environment demands new skills of learners and educators [18,19].

These changes can only be achieved through the implementation of public policies by the government. In Ecuador's case, the Ten-Year Education Plan 2016-2025 [20] emerged from a series of actions proposed by teachers to develop various public policies, such as universal education, eradication of illiteracy, improvement of infrastructure and quality of education and public investment. With these changes, education programs have a great future. Pearson [21] recently highlighted six post-pandemic programs that will mark the future; among them is education.

\subsection{Global Trends in Education Programs}

When referring to education as a profession, one must go to the root and ask if universities adequately train professionals in education. A common problem facing education is connecting theory and practice. To bridge the gap, Westbury, Hansén, Kansanen and Björkvist [22] suggest that teacher preparation should include broader contact with all the elements that generally comprise a teacher's job. Sachs [23] stresses this is achieved through a more collaborative and research-engaged teaching profession.

Economic problems add to the research issue. In recent years, costs have increased for private education, public education, promotion of inclusion, growth in enrollment rates and funding, among others [24]. Education programs, like health programs, are considered to be of public interest [25] and are increasingly in demand. Teaching programs should be considered in effective policies that reflect the profession's value, expressed with adequate remuneration. Teachers must be economically positioned to improve their living and working conditions, stimulate the profession and encourage the entry of competent people to become and remain good teachers and professors [26]. The educational process has changed since the pandemic, and connectivity played an important role $[27,28]$. This factor is a crucial part of new teaching and learning modalities, where accessibility and mediation through electronic devices and more flexibility of curricular itineraries prevail [29-31]. 
Therefore, there is an increasing interest in online education, which is reflected in the demand for Massive Open Online Courses (MOOCs) [32].

Training in education programs requires a push for active learning strategies. Bucklin et al. [33] state that more efforts are needed to increase innovation and incorporate evidence-based active media education strategies, especially to foster student engagement, critical thinking and problem-solving skills. Bermejo Díaz et al. [34] had very satisfactory and promising results in subject assessment through cooperative learning, using variables such as satisfaction, performance, student involvement and teacher assessment. They proposed including cooperative learning and subject content in learning methodology. Another of the strategies studied by Giles Girela et al. [35] was Service-Learning, to improve managerial competencies in the initial training of teachers as they experience their first contact with the reality of the classroom, fundamental in the entire training process. Training in active strategies, integrated into experiential learning designs, can contribute to the formation of competencies.

Recent studies of education programs indicate specific competencies valued in training. Among primary education students in Spain, Espejo-Garcés et al. [36] found that young people who have a higher general self-concept and good self-emotional management skills obtain a university degree through vocational training. Ferro et al. [37], in a study with future physical education teachers in 23 universities in Chile, found that the most recognized competencies were (a) critical interpretation of knowledge and reflection on pedagogical and professional practice; (b) designing and applying learning and evaluation activities and (c) collaborative work and leadership. Ciesielkiewicz et al. [38] conducted a study of Spanish university students in a degree program in Early Childhood and Primary Education. They participated in an international service-learning project and used an electronic portfolio (ePortfolio) to document and evaluate competencies in three dimensions specified in the education degree program: acquisition and use of technologies, problemsolving and global issues. This project coincided with a comparative study of pedagogy employed with engineering students, where the integration of knowledge management in various fields was supported by Information and Communication Technologies (ICTs) [39]. In another study of future physical education teachers, students started with the idea that to teach, it would be necessary to master teaching education contents and other didactic elements. However, it was found that the active-learning practice activities for these students who had no face-to-face teaching experience were decisive in giving meaning to the subject [40].

Along these lines, this study aims to provide perspectives on the future of educational programs by analyzing trends in educational programs' designs, students and professors' needs for innovative education. This study will be helpful for stakeholders such as decision-makers, academicians, curriculum developers, researchers, students and social organizations interested in education programs. However, the data may be of interest to other disciplines in different areas.

\section{Materials and Methods}

The research methodology applied was the descriptive/exploratory case study using quantitative and qualitative instruments [41]. The selected method represents the researchers' interest in analyzing how real phenomena affect education, collecting data from various information sources like surveys, interviews, focus groups and benchmarking [42] to explore, understand and describe in-depth the social and educational scenarios [43] for the future of educational programs at the Universidad Técnica Particular de Loja (UTPL) in Ecuador. The units of analysis for the study were: (1) characteristics of education programs, (2) student requirements, (3) required educational modalities, (4) trends in education and (5) future of education programs. 


\subsection{UTPL Context}

The Universidad Técnica Particular de Loja (UTPL) is a private Ecuadorian university. It was founded by the Ecuadorian Marist Association (AME) on 3 May 1971, to respond to the need for technical and humanistic training in the southern region of Ecuador. The Ecuadorian government officially recognized it under Executive Decree 646, published in the official registry No. 217 on 5 May 1971.

UTPL offers 23-degree programs in on-site modality, 17 in at a distance modality and 5 postgraduate programs. Currently, there is a teaching staff of 1070 professors, of which 132 are Ph.Ds., 692 hold master's degrees and 246 are obtaining their fourth-level degree in different fields of knowledge.

In education, the following are offered in at a distance education: Early Childhood Education, Primary Education, Religious Studies (Religious Education), Language and Literature Pedagogy, Chemistry and Biology Pedagogy, Mathematics and Physics Pedagogy, National and Foreign Languages Pedagogy, and Psychopedagogy. Master's degree programs include Education with a mathematics minor and Pedagogy of National and Foreign Languages with a minor in English teaching. These degrees are available in more than 80 UTPL centers in the 24 provinces and 3 international ones in Rome, New York and Madrid.

\subsection{Participants}

For the present study, 5 population segments were selected by simple random sampling: (1) 337 current UTPL Education Sciences students, (2) 384 potential students, (3) 313 UTPL Education Sciences graduates, (4) 20 interviewees: education experts from Mexico, Spain, Colombia and Ecuador, and (5) 32 education professionals (rectors, directors, elementary, secondary and university teachers and specialists) who participated in the four focus groups.

The participants' characteristics in terms of age, gender, are shown in Figure 1 and place of residence is shown in Table 1, where it can be seen that in segments 1, 2 and 3, more than $76 \%$ were female. In population segment 4 , a relatively high percentage $(56.3 \%)$ were female, while in the last segment, the female gender represented only $20 \%$. The first group's average age was 29, while for groups 2 and 3, it was 37. Finally, the four population segments were located in different cities in the 24 provinces of Ecuador; groups 1, 2, 3 and 4 predominantly came from the provinces of Azuay, Loja, Guayas and Pichincha. In group $5,50 \%$ were international experts from foreign countries, and the other $50 \%$ were nationals from Loja (15\%), Manabí (5\%) and Pichincha (30\%).

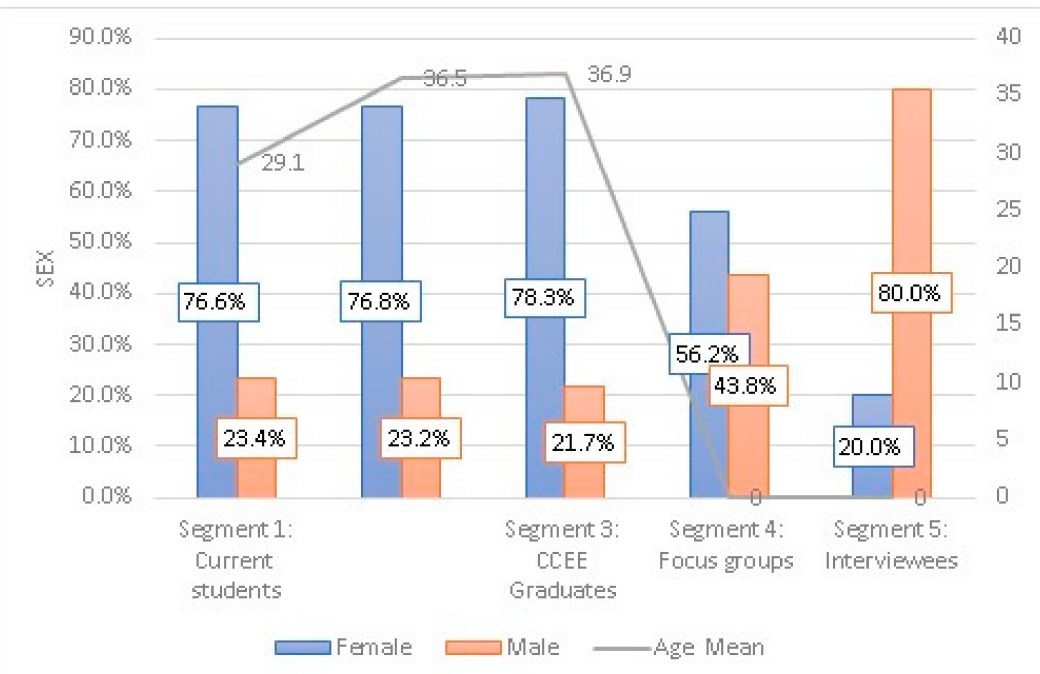

Figure 1. Characteristics of the population and segments (Own elaboration). 
Table 1. Population place of residence (Own elaboration).

\begin{tabular}{|c|c|c|c|c|c|c|}
\hline Place of Residence & Azuay & $14.5 \%$ & $4.9 \%$ & $11.8 \%$ & $9.4 \%$ & $0.0 \%$ \\
\hline & Bolivar & $0.0 \%$ & $0.3 \%$ & $1.0 \%$ & $0.0 \%$ & $0.0 \%$ \\
\hline & Cañar & $2.4 \%$ & $0.8 \%$ & $7.7 \%$ & $3.1 \%$ & $0.0 \%$ \\
\hline & Carchi & $0.0 \%$ & $0.3 \%$ & $1.6 \%$ & $0.0 \%$ & $0.0 \%$ \\
\hline & Chimborazo & $0.0 \%$ & $1.6 \%$ & $2.9 \%$ & $0.0 \%$ & $0.0 \%$ \\
\hline & Cotopaxi & $0.0 \%$ & $0.5 \%$ & $3.2 \%$ & $0.0 \%$ & $0.0 \%$ \\
\hline & El Oro & $5.9 \%$ & $7.6 \%$ & $8.6 \%$ & $0.0 \%$ & $0.0 \%$ \\
\hline & Esmeraldas & $0.0 \%$ & $2.6 \%$ & $1.3 \%$ & $0.0 \%$ & $0.0 \%$ \\
\hline & Foreign Countries & $0.0 \%$ & $0.0 \%$ & $0.6 \%$ & $3.1 \%$ & $50.0 \%$ \\
\hline & Galapagos & $0.0 \%$ & $0.0 \%$ & $0.3 \%$ & $0.0 \%$ & $0.0 \%$ \\
\hline & Guayas & $11.0 \%$ & $29.6 \%$ & $9.9 \%$ & $9.4 \%$ & $0.0 \%$ \\
\hline & Imbabura & $0.0 \%$ & $2.1 \%$ & $2.9 \%$ & $3.1 \%$ & $0.0 \%$ \\
\hline & Loja & $11.6 \%$ & $8.6 \%$ & $14.1 \%$ & $37.5 \%$ & $15.0 \%$ \\
\hline & Los Rios & $0.0 \%$ & $1.6 \%$ & $0.6 \%$ & $0.0 \%$ & $0.0 \%$ \\
\hline & Manabí & $1.8 \%$ & $8.3 \%$ & $1.3 \%$ & $0.0 \%$ & $5.0 \%$ \\
\hline & Morona Santiago & $0.0 \%$ & $2.1 \%$ & $1.3 \%$ & $3.1 \%$ & $0.0 \%$ \\
\hline & Napo & $0.0 \%$ & $1.3 \%$ & $0.0 \%$ & $0.0 \%$ & $0.0 \%$ \\
\hline & Orellana & $0.0 \%$ & $1.6 \%$ & $0.6 \%$ & $0.0 \%$ & $0.0 \%$ \\
\hline & Pastaza & $0.0 \%$ & $0.5 \%$ & $0.0 \%$ & $0.0 \%$ & $0.0 \%$ \\
\hline & Pichincha & $52.8 \%$ & $16.6 \%$ & $26.2 \%$ & $25.0 \%$ & $30.0 \%$ \\
\hline & Santa Elena & $0.0 \%$ & $3.9 \%$ & $0.6 \%$ & $0.0 \%$ & $0.0 \%$ \\
\hline & Santo Domingo de los Tsáchilas & $0.0 \%$ & $2.1 \%$ & $1.6 \%$ & $0.0 \%$ & $0.0 \%$ \\
\hline & Sucumbíos & $0.0 \%$ & $0.8 \%$ & $0.3 \%$ & $0.0 \%$ & $0.0 \%$ \\
\hline & Tungurahua & $0.0 \%$ & $1.8 \%$ & $0.6 \%$ & $6.3 \%$ & $0.0 \%$ \\
\hline & Zamora Chinchipe & $0.0 \%$ & $0.5 \%$ & $1.0 \%$ & $0.0 \%$ & $0.0 \%$ \\
\hline
\end{tabular}

For ethical considerations, the participants were informed that the data would be used for academic purposes, and they voluntarily consented to participate. The data was handled objectively and were relevant to the evidence presented. Finally, the dissemination of the study data respected the participants' privacy and adhered to the institutional policies.

\subsection{Development of the Research}

The innovative education program project was developed in two phases: the feasibility study and the pedagogical-curricular design [44]. This study includes information related to phase one, including a market study using surveys, interviews and focus groups with students, graduates and educational experts and a benchmarking of 10 national and international universities' best practices in their education programs.

\subsubsection{Instruments}

The following instruments were applied to explore the study's units of analysis:

Benchmarking. The benchmarking objective was to identify the characteristics of education programs through analyzing data from 10 institutions. The 10 universities' selection was based on a purposeful sampling of best practices in education programs and QS ranking positions. The benchmarking process improves organizations' effectiveness and efficiency and updates current methodologies [45]. The study was conducted based on 
educational categories and indicators of interest to learn about good educational innovation practices.

Surveys. For the surveys, the target population was students in the education programs, graduates of these programs and potential students (high school graduates). We used databases provided by the university and secondary databases. To define the sample, we applied a formula for finite universes and a weighting. A total of 337 current students, 313 graduates and 384 potential students were surveyed. A diagnostic instrument from a Mexican university [46] was adapted to the Ecuadorian context. Before its application, the instrument underwent a validation process by experts. The survey consisted of three questions to analyze students' requirements in educational programs: why they study education, the modality they prefer and the competencies they want to develop in education programs. The survey was applied using SurveyMonkey through e-mails and telephone calls.

Focus groups. The focus groups explored the educational modalities desired in programs, trends in education and the future of educational programs in Ecuador. There were four sessions with 32 education professionals, including rectors, school principals and university professors and specialists.

Interviews. The interviews were applied to experts in the area of knowledge of education. Twenty in-depth interviews were conducted with experts from Mexico, Spain, Colombia and Ecuador. Audio and video recordings were used with the participants' prior consent. From the interviewees' answers, we constructed a guide with about eight questions to explore the units-of-analysis of trends in education and the future of educational programs in Ecuador.

\subsubsection{Data Analysis}

Quantitatively, the data from the population segments 1, 2 and 3 surveys were processed systematically using Excel and the SPSS program (v.22.0). Qualitatively, the Benchmarking and focus group data from population segments 4 and 5 were processed using NVivo11 software. The data validation strategy was carried out with triangulation of the results under the theoretical framework that supported the analysis to have valid and reliable interpretations and conclusions.

\section{Results}

The results presented below are based on the units-of-analysis data.

\subsection{Characteristics of Education Programs}

Most of the higher education institutions in Ibero-America have education-related programs. This section of the paper presents the benchmarking of 10 institutions, almost all are included in the QS ranking to show the characteristics of education programs. The following institutions in Ecuador were selected for benchmarking: Universidad de las Fuerzas Armadas, Universidad San Francisco de Quito, Universidad Católica de Santiago de Guayaquil, Universidad Nacional de Educación and Universidad del Azuay. Outside Ecuador, the Universidad Internacional de la Rioja, Pontificia Universidad Católica de Chile, Universidad de Sao Paulo, Tecnológico de Monterrey and Universidad de los Andes were selected. The comparisons of the ten selected institutions are presented in Table 2.

The benchmarking institutions analyzed included elements such as digital transformation, research, self-management capacity and innovative entrepreneurship. Their educational programs are oriented towards developing skills in students that contribute to research and the discovery of societal needs by integrating educational practices and ICTs through e-learning and b-learning. 
Table 2. Benchmarking of ten Ibero-American universities (Own elaboration).

\begin{tabular}{|c|c|c|c|c|}
\hline University & $\begin{array}{l}\text { QS World University } \\
\text { Rankings } 2021\end{array}$ & Country & $\begin{array}{l}\text { Educational Programs Offered } \\
\text { by the University }\end{array}$ & Characteristics \\
\hline University of Sao Paulo & 115 & Brazil & Bachelor's Degree in Pedagogy & $\begin{array}{l}\text { The program encourages student research in education and } \\
\text { university extension. }\end{array}$ \\
\hline $\begin{array}{l}\text { Pontificia Universidad } \\
\text { Católica de Chile. }\end{array}$ & 121 & Chile & $\begin{array}{l}\text { It offers a Pedagogical Training } \\
\text { Program that supports first-year } \\
\text { students in different areas as they } \\
\text { enter university life. }\end{array}$ & $\begin{array}{l}\text { The training program seeks to develop lifelong and } \\
\text { environmental competencies and to train professionals to } \\
\text { have ethical and responsible attitudes. }\end{array}$ \\
\hline University of La Rioja & Not ranked. & $\begin{array}{l}\text { Spain with a Latin } \\
\text { America presence. }\end{array}$ & $\begin{array}{l}\text { It offers a degree in Early } \\
\text { Childhood Education with a "zero } \\
\text { semester" to familiarize new } \\
\text { students with its curriculum. }\end{array}$ & $\begin{array}{l}\text { The outreach is extended to social sectors having educational } \\
\text { projects, such as hospitals, language centers, nurseries, } \\
\text { museums, galleries, publishing houses, sports centers and } \\
\text { clubs, libraries, tourism sectors, prisons and special education } \\
\text { centers (residences, NGOs, speech therapy). }\end{array}$ \\
\hline $\begin{array}{l}\text { University of the Armed } \\
\text { Forces }\end{array}$ & $1001+$ & Ecuador & $\begin{array}{l}\text { It offers a bachelor's degree in } \\
\text { Initial Education Sciences. }\end{array}$ & $\begin{array}{c}\text { It gives weight to research, has a Center for Nanoscience and } \\
\text { Nanotechnology, and a Center for Scientific and Technological } \\
\text { Research of the Army. It offers both classroom and } \\
\text { e-learning training. }\end{array}$ \\
\hline $\begin{array}{l}\text { Universidad San Francisco } \\
\text { Quito }\end{array}$ & $751-800$ & Ecuador & $\begin{array}{l}\text { It offers a Bachelor's degree in } \\
\text { Education Sciences. }\end{array}$ & It promotes a comprehensive liberal arts education. \\
\hline $\begin{array}{l}\text { Catholic University of } \\
\text { Santiago de Guayaquil }\end{array}$ & 251-300 LATAM Ranking & Ecuador & $\begin{array}{l}\text { It offers a bachelor's degree } \\
\text { in Education. }\end{array}$ & $\begin{array}{l}\text { It is connected to undergraduate programs in which certain } \\
\text { subjects have been as-signed as integrating chairs, having } \\
\text { theoretical and practical elements. In addition to internships } \\
\text { in the subjects of their current study programs, the students } \\
\text { also complete community and pre-professional internships. }\end{array}$ \\
\hline
\end{tabular}


Table 2. Cont.

\begin{tabular}{|c|c|c|c|c|}
\hline University & $\begin{array}{l}\text { QS World University } \\
\text { Rankings } 2021\end{array}$ & Country & $\begin{array}{c}\text { Educational Programs Offered } \\
\text { by the University }\end{array}$ & Characteristics \\
\hline University of Azuay & $\begin{array}{l}\quad 351-400 \\
\text { LATAM Ranking }\end{array}$ & Ecuador & $\begin{array}{c}\text { It offers a bachelor's degree in } \\
\text { Basic Education. }\end{array}$ & $\begin{array}{l}\text { It seeks to develop ethical judgment and attitudes in the } \\
\text { students. It promotes self-evaluation and social responsibility } \\
\text { in the teaching programs. } \\
\text { The program develops students to act proactively and dialog } \\
\text { in socio-educational contexts; promotes social transformation } \\
\text { at regional and national levels through teaching action; } \\
\text { designs, implements and evaluates educational programs that } \\
\text { are inclusive and contextual, and projects for Primary } \\
\text { Education. It uses the b-learning modality. }\end{array}$ \\
\hline $\begin{array}{l}\text { National University of } \\
\text { Education }\end{array}$ & Not ranked. & Ecuador & $\begin{array}{l}\text { It offers a Bachelor of Science in } \\
\text { Primary Education program. }\end{array}$ & $\begin{array}{l}\text { It offers personalized tutoring. In Ecuador, unlike other } \\
\text { countries, it is common to use integrative chairs within } \\
\text { their programs. }\end{array}$ \\
\hline Tecnologico de Monterrey & 155 & Mexico & $\begin{array}{l}\text { Tecnologico de Monterrey recently } \\
\text { opened the bachelor's degree in } \\
\text { Educational Innovation. Students } \\
\text { can obtain one of the following } \\
\text { specializations: a) Design of } \\
\text { learning models and } \\
\text { environments, b) Management of } \\
\text { educational solutions or c) Digital } \\
\text { humanities. Tecnologico de } \\
\text { Monterrey seeks to be at the } \\
\text { forefront of education worldwide } \\
\text { and promotes comprehensive } \\
\text { education for its students. }\end{array}$ & $\begin{array}{l}\text { Two years ago, this institution fully implemented its new } \\
\text { Tec21 Educational Model structured with learning blocks for } \\
\text { active learning. The students enroll in an innovative "Semester } \\
i \text { " for immersion in a labor field contextual to the programs } \\
\text { they are studying to collaborate with industry and } \\
\text { government partners to solve real-world challenges. }\end{array}$ \\
\hline
\end{tabular}




\subsection{Student Requirements}

To learn about the students' requirements, we asked about their reasons for studying in the education programs. The most important reasons for current students were teaching quality $(67.1 \%)$, obtaining certifications $(65 \%)$ and scholarships and the mode of study $(62.3 \%)$. In the case of graduates, the reasons were personal vocation $(93 \%)$, family opinion (59\%) and income potential (49\%). Potential students mentioned personal improvement $(30.29 \%)$, improving their professional profile $(8.07 \%)$ and obtaining knowledge $(5.57 \%)$.

Regarding the study modality, $97 \%$ of potential students responded that studying in the virtual mode should be flexible to facilitate both their work and personal lives. A total of $89.7 \%$ of education graduates considered it very important to have adequate synchronous sessions. At the same time, $93.5 \%$ of current students considered it very important that the teaching-learning strategies used in this modality be excellent.

Regarding the competencies developed in education programs, current students mentioned critical and creative thinking (65\%), innovative entrepreneurship (55\%) and problem-solving and adapting to difficulties (50\%). Graduate students considered the crucial competencies to be digital transformation $(80.2 \%)$, reasoning for complexity $(78.3 \%)$ and ethical and citizen commitment $(78 \%)$. In the case of potential students, the essential competencies were research $(77 \%)$, self-management $(72 \%)$ and ethical and citizen commitment (72\%). (See Figure 2).

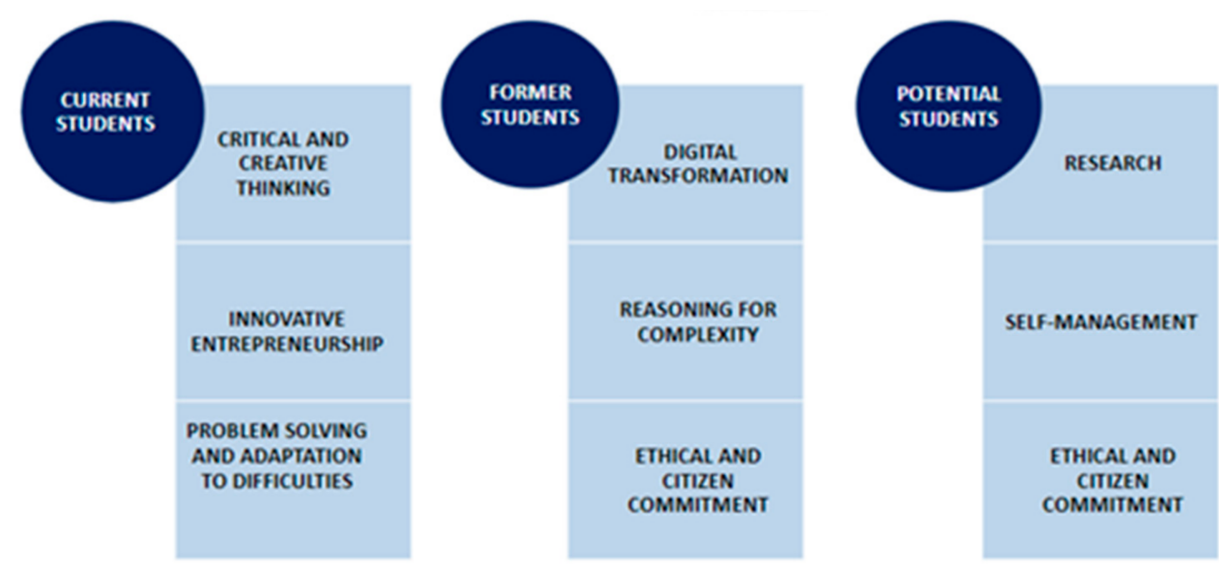

Figure 2. Competencies to be developed in the education programs (Own elaboration).

\subsection{Required Educational Modalities}

According to the focus groups, there is a need to have virtual and hybrid models where face-to-face and virtual sessions are mixed, using e-learning and blended learning systems (b-learning). "In the event that education programs are virtual, they will have to be completely transformed" is the expression of most of the interviewees.

In this same perspective, potential students, current students and graduates considered that a virtual program requires changes in a large number of factors: "the way of evaluating the student," "the way of giving meaningful class-activities," "the system of follow-up and accompaniment of the teacher," "minimizing the contents through virtual sessions," and "adequate management of emotions and strengthening motivation through the screen." All these comments imply that "the development of teaching-learning strategies used in this modality must be excellent," as expressed by $93.5 \%$ of those surveyed.

Despite the above considerations, the interviewees and respondents valued the virtual modality as the option offering them the best opportunity to work (13\%), study $(10.87 \%)$ and have flexible schedules and time (8.39\%). Figure 3 below is a word cloud from the responses showing their relative frequencies, indicated by size. 


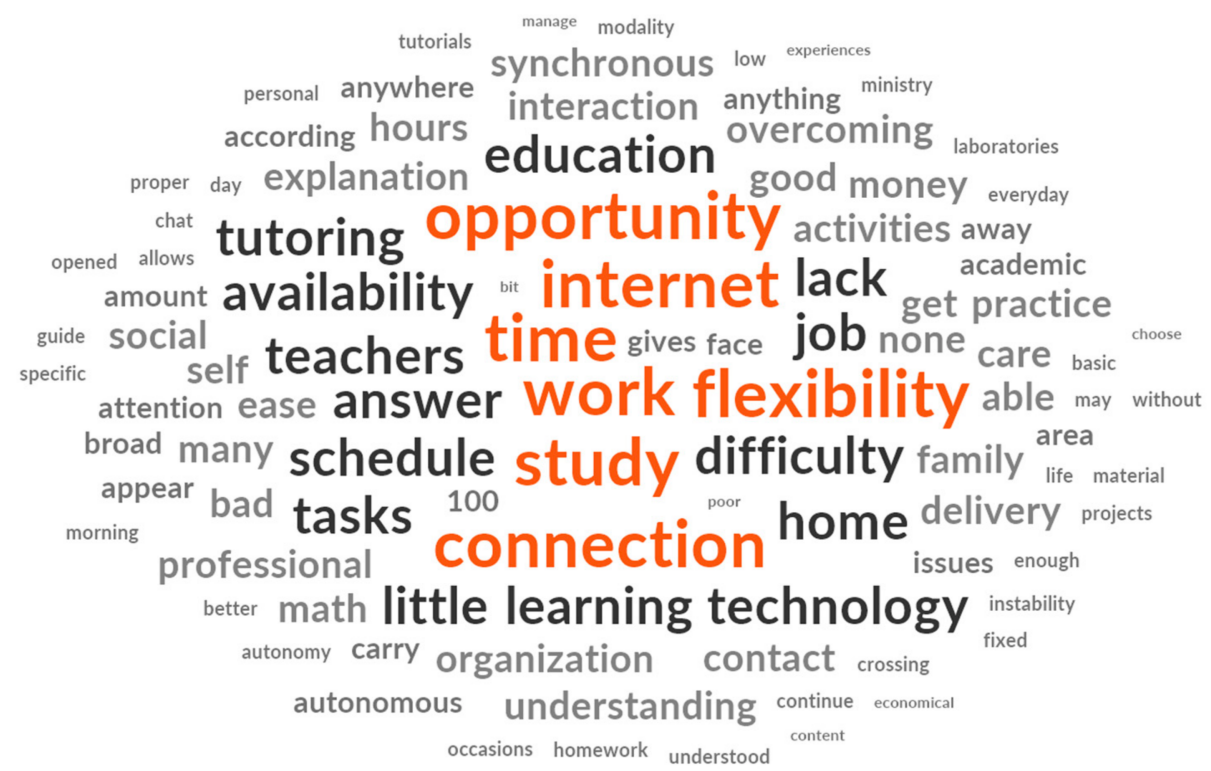

Figure 3. Opportunities offered by the virtual modality (Own elaboration).

\subsection{Trends in Education}

Experts believe that education will not be the same in the future. In the consultations conducted in the interviews and focus groups, the education trends presented in Figure 4 were explored. These trends include artificial intelligence, the flexibility of the educational offerings, the transformation of the teaching role and the educational environment's digitalization.

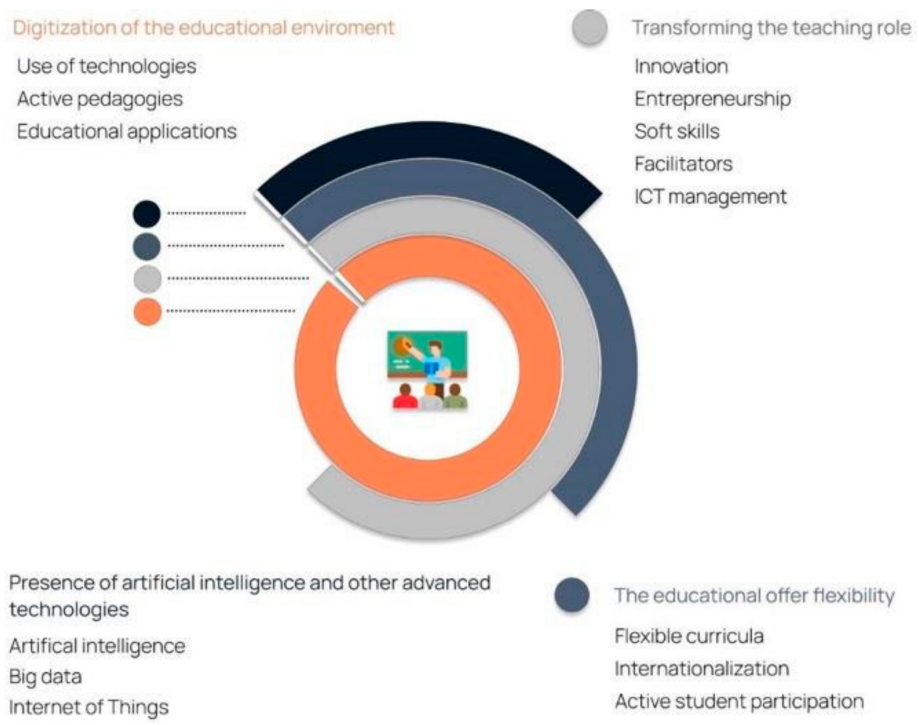

Figure 4. Trends in education (Own elaboration).

One of the trends, artificial intelligence is, among the technologies, the one that promotes the educational process's disintermediation. In this sense, teachers will have to share the stage with artificial intelligence systems and acquire competencies in Big Data, the Internet of Things and other technologies applicable to education. Classes will no longer be taught in the same way. One of the experts indicated, "There must be some changes. It will no longer be necessary training or knowledge that students can find easily on the Internet. They must learn procedures, how to develop routines and develop algorithms. That will be the starting point for teaching in the future". 
A critical trend to consider is the educational offering's flexibility to adjust the educational programs' curricula and structures. As an expert commented, "This flexibility would allow correcting the problem of program rigidity. The curricula must be open to other disciplines, where teachers from different countries participate and the student does not need to come every day to class. There should be more active participation of the students".

Another trend is the transformation of the teacher's role. Future teachers must be trained in innovation. In one of the focus groups, it was commented, "Currently, the world requires innovation, creativity and entrepreneurship relevant to the country and the world. People must have the ability to look beyond, adapt, innovate and create, not going back to the same thing because, in the future, there will be more unemployment. "A comment in another group was, "We must look for subjects that allow the future teacher to grow and acquire knowledge with ICT. Difficulties or problems will arise that must be resolved, so all teachers must be able to handle this knowledge".

On the other hand, they also agree that it is essential to strengthen soft-skills development. For the experts, the changes should involve technological issues, but the teacher should be a facilitator and guide throughout the learning process. Teachers should have experience with reality from the beginning of their education program. As one of the experts commented, "Now the great challenge is to strengthen the set of soft skills, such as socio-emotional skills." Another expert commented, "There are a series of soft skills that teachers must use in the treatment of students: monitoring, empathizing —all these factors greatly influence the development of the whole classroom environment and the behavior and responses of students. The teachers must connect, excite and involve students in these processes".

Experts believe that teachers should stop being mere communicators of content and become facilitators of the learning process. They should assume the role of a coach and designer of learning experiences, not a repeater or transmitter. As they commented, "The teachers must genuinely believe they are a coach, facilitator, one who supports, guides, follows, leads and facilitates so the students can learn. In teaching, they cannot deviate from the competencies that the student must develop." The comments expressed the need for self-learning in students, for them to develop skills to learn autonomously. They also contributed that, "The teacher of the 21st century is a facilitator, a collaborator, is digitally competent, a person who works in a team and who learns continuously, this is very important. He or she must be a person who is continuously researching, learning, applying and experimenting in their classes and educational activities. This is since they are generating a process of innovation, doing something different, looking for process improvement that can capture and generate emotion and memorable learning in students".

The participants considered it fundamental that new teachers be human first and foremost and promote a series of values among students: humanism, empathy and emotional intelligence. Inserting neuroscience in learning environments: in one of the focus groups, it was commented, "Work on all the teacher's skills, empathy, emotional intelligence, solidarity, human aspects, critical thinking, self-regulation, adaptability, communication, creativity, compassion, digital skills and resilience".

Finally, the other major trend is the digitalization of the educational environment and the teaching and learning process. The emerging technologies trend will accompany education in the coming years and more intensive virtual pedagogy and searches for active educational applications. As mentioned in one of the groups, "Teachers must face both the new and current challenges, such as working virtually, and digital competencies training is needed to develop these tasks".

\subsection{Future of Education Programs}

For the experts, changes should be made in the assessment systems: evaluation by competencies according to the modality. The need to strengthen the research processes carried out by teachers is also recognized. Teachers should no longer teach content because knowledge is everywhere, and they should reorient their teaching role. In the future, classes 
should be spaces for reflection and debate and not just the transmission of knowledge. Pedagogy and didactics need to be strengthened. ICTs have changed assessments. As one of the experts commented, "Evaluation will have to be based on Big Data, using algorithms to monitor the students' learning, to see effectively who has entered the online session and why they have not entered. If they clicked twenty times on a single link, why are they interested in that material? Did they consult it for a specific purpose? If they never entered the platform, why didn't they? If they clicked too many times, why is it complicated to use the platform? We must discover the answers. These are new areas of opportunity".

The ideal education programs should have direct contact with reality. Putting aside jealousies and walls between the different subjects in education programs and other disciplines has to end. Future education programs will have a multi- and trans-disciplinary look. As mentioned by one of the experts, "A formative process is needed where the field requires an interdisciplinary look, a repositioning of the field within the educational sciences, giving a sense of humanity".

Another characteristic pointed out by the participants is the need to have teachers who speak at least one additional language. As mentioned by the experts, "Given that we live in a globalized world and that much knowledge is published in English, it is unthinkable that in the future there will not be a program that privileges the teaching of several languages". Future education programs must be multidisciplinary, flexible and predominated by inverted classrooms. As one of the experts mentioned, "In this exercise of research training, both in instrumental and methodological terms, there is a dimension to be addressed, which is the multidisciplinary nature of the social sciences and educational sciences. The exercise must recover the link between education and the social world, allowing a deep connection with cultures". A mixed system (blended) is preferred where face-to-face and online moments are interspersed. To be effective, it will be necessary to strengthen pedagogy and didactics and technological competencies, soft skills, changes in evaluation systems and a total rethinking of the work modality.

An ideal program should train teachers who show leadership skills and who are, above all, human. It implies a lot of creativity and innovation so that future teachers are constantly innovating and imaginatively creating new ways to access knowledge. The education programs must respond to the labor market demands, as mentioned in one of the focus groups: "The programs that are proposed must respond to the occupational demand of local and global reality. It is essential to promote the rigidly structured but versatile work environments and resolve real problems". "Current market trends and the development of society point towards telework, not only in manufacturing and industry; therefore, it is necessary to broaden the concept of training, based on technologies, critical thinking and entrepreneurship".

Another characteristic pointed out by the participants was the use of new technologies, without which the transmission of knowledge will be impossible in the future. There is the need to generate vocations in future teachers, a taste for research, new evaluation systems and students' skills and abilities to undertake future projects.

New work modalities should be implemented, including follow-up, feedback, teacher accompaniment, storytelling, theater classes, acting, creative management of expectations and content organization in virtual sessions. In the focus groups, it was commented that "education and learning must be utilitarian and practical. Teachers or parents should not be concerned about the grade but what they do with what they know. Subjects that are useless for the future should be eliminated. In addition, highlight the issue of entrepreneurship. Today we see the collective's need to undertake tasks other than the traditional ones to strengthen the economy. Education should be focused on the skills of living, teaching entrepreneurship that is utilitarian and practical".

The second component of most concern is managing emotions, given the recent distancing caused by the pandemic, which has resulted in the absence of physical contact and relationships through a screen. 
For future needs, it is suggested to include virtual education, inclusive education, education across the world, educational policies, learning for the world of work, teaching in research, technological innovation and decision-making. Both students and experts agree that training should be more practical, where digital transformation, research, selfmanagement and innovative entrepreneurship are included. As they mentioned in the focus groups, "There should be creativity fundamentally to generate entrepreneurship and motivate innovation, open and flexible to changes, with techniques and technologies". Another commented, "Current market trends and societal development point towards telework not only to manufacturing and industrial work; therefore, it is necessary to broaden the concept of training, based on technologies, critical thinking and entrepreneurship".

Experts also indicate program flexibility as a necessity. The curriculum should be multidisciplinary with active student participation, with hybrid and virtual models such as the flipped classroom that do not prioritize only content. The evaluation models must change to assess functional competencies; the classroom becomes a space for reflection and debate. Figure 5 shows the main elements for the new education program.

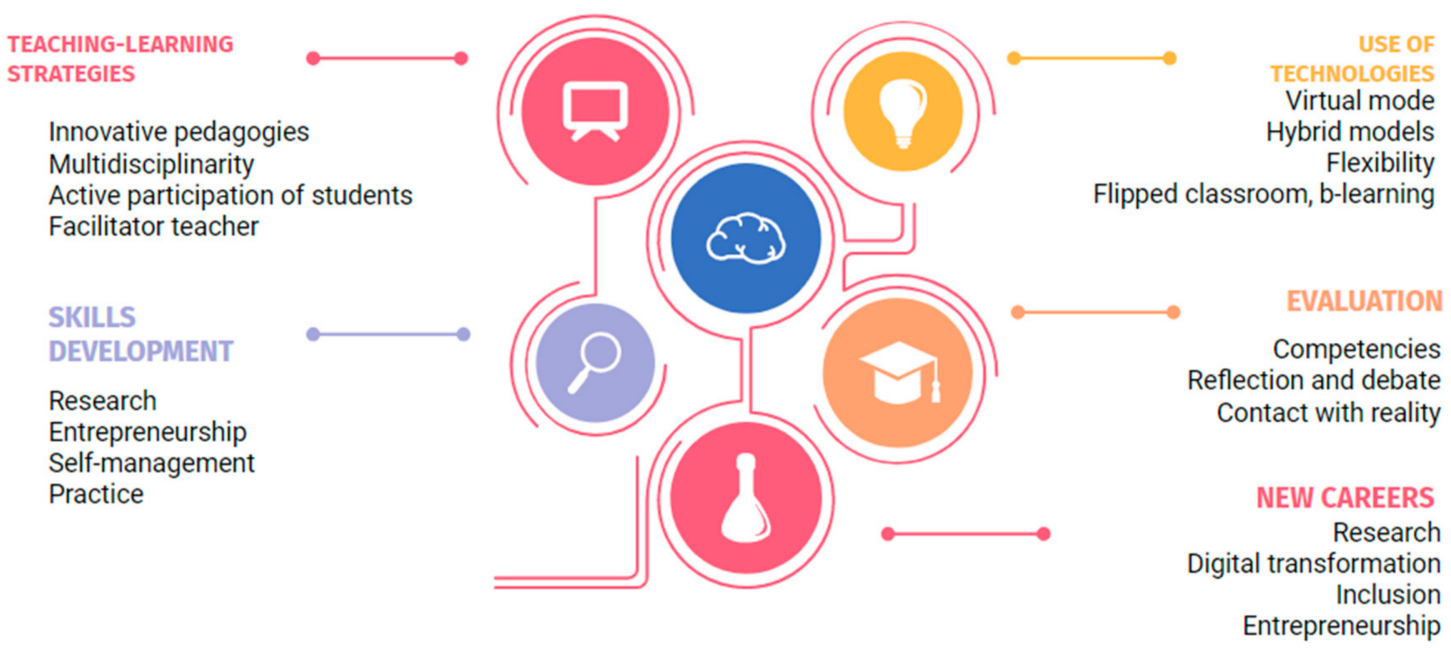

Figure 5. Characteristics of education programs (Own elaboration).

These new programs require contact with reality, where the teacher is a coach and facilitator of learning. Therefore, the pedagogy must be reviewed and supported by new technologies. Regarding innovative educational programs, this study determined that it requires the incorporation of five fundamental elements: (1) the incorporation of teachinglearning strategies that include innovative pedagogies, multidisciplinarity and active student participation, where the teacher is a facilitator of student learning; (2) development of skills in research, entrepreneurship, self-management and professional practice; (3) the use of technologies in virtual and hybrid modalities in flexible environments; (4) assessments of competencies that promote debate and reflection and are relevant to the reality that the future teacher will face; and (5) new programs that provide training in entrepreneurship, digital transformation, inclusion and research. Figure 5 shows the main elements of these new education programs.

\section{Discussion}

Education programs in most universities in Ibero-America seek to develop skills in students that contribute to research, discover societal needs and integrate distance education modalities; however, we found that they still want a high face-to-face component. According to the university benchmarking results shown in this research, the offerings of these programs increasingly seek to develop life skills in students, research, critical thinking, social responsibility and comprehensive training of students. As UNESCO [26] mentioned, teacher training should include broader elements than those offered in traditional programs, 
strengthening teachers' conditions and recognizing their work and encouraging young people to enter these programs. Hence, the new education programs should develop competencies related to research and contribute value to society. The training in new technologies contributes to global education that is oriented toward improved teacher training conditions.

Students' requirements for education programs relate to teaching quality, vocation and self-improvement, developing competencies to perform adequately in the work world they will face and virtual training to complement other areas of their lives. This study shows that the competencies most desired in education programs by current students are critical thinking, innovative entrepreneurship and problem-solving. For graduate students, they are digital transformation, the reasoning for complexity and ethical commitment, while for potential students, they are research, self-management and ethical commitment. This coincides with studies conducted in education programs where students value these competencies in their training [9-11]. In addition, these studies show the need to develop different teaching modalities where the technological component acquires greater relevance $[36,37]$. Including these characteristics in education programs will favor training teachers in the necessary competencies to be better prepared to work in their environments with technological skills that benefit and strengthen all aspects of their students' lives.

Social transformations and universities' new training requirements point to new study modalities, where accessibility, flexibility and mediation of learning in virtual and hybrid environments are prioritized. This research confirms that virtual models offer better opportunities for teacher training. The work of the present study agrees with that previously reported by Keengwe and Kidd [7]; Adams, Cummins, Davis, Freeman, Hall and Ananthanarayanan [29], who established that online learning is adequate due to its flexibility. Other research studies $[8,29,32]$ suggest that online learning should be encouraged because of ease-of-access through electronic devices supporting adaptive learning, as shown in this pandemic time. These modalities are considered to diversify teacher training and facilitate new ways to manage, evaluate and motivate learning through virtual environments.

The trends in education programs show the increasing use of artificial intelligence, the flexibility of educational offerings, the transformation of the teaching role and the educational environment's digitalization. This agrees with other studies where trends in educational training link to process changes and results lead to a culture of innovation, improvements in assessment, collaborative and deep learning, redesign of educational spaces, student-centered learning and enhanced commitment $[5,6]$. These dynamics point to a more significant technological presence and automation of tasks, adaptive curricular itineraries, a new role of the teacher as facilitator, motivator and companion and digitalized teaching-learning processes.

Innovation in education programs is presented as a promising process that will mark the post-pandemic future of university academic offerings. The innovative pedagogicalcurricular model proposed in this study incorporates active and collaborative teachinglearning strategies that are innovative and multidisciplinary. The model promotes student participation that the teacher facilitates. Characteristics include research, entrepreneurship, self-management and practical skills that graduates will need in the work world. The model conceives personal, professional and social development. Technologies are employed in flexible environments presented in virtual and hybrid modalities that mediate learning. Assessments become competency-based; they consider debate and reflection and experience with professional reality. New professional opportunities arise from education programs that train in entrepreneurship, digital transformation, inclusion and research. The teaching-learning strategies in this innovative model are consistent with the findings of Bucklin et al. and Bermejo Díaz et al. 33,34], where it is established that training in education programs must impulse active and cooperative learning strategies to increase student satisfaction, performance, engagement and teacher evaluation. 
Regarding professional training, other authors agree that learners must possess new competencies [18] such as leadership, communication, critical thinking, creativity, innovation, social intelligence, ethical commitment, empathy, human sense, entrepreneurship, research, inclusiveness, respect for diversity, self-learning, social responsibility, teamwork and digital competencies. These reflect knowledge development from an academic perspective also [9-11].

As for technologies, they are resources that mediate such experiences and adapt and follow the students in real-time, providing actionable data $[17,29]$. Regarding assessment, studies support that it should be done by competencies so that students can reflect on the development of knowledge and their contribution to society [10,11]. Along these lines, research results highlight that it is increasingly necessary to transform programs in the field of education, where professional opportunities demand innovation, life skills, active methodologies and new forms of evaluation, among others.

This study allowed us to know the opinions of the participants in the educational process about the future of programs in education. On the one hand, students require flexible programs that allow them to combine their daily activities such as work and family with study, with quality education. On the other hand, experts give special attention to the digital transformation in educational processes and the importance of the transformation of the role of the teacher towards a role of learning guide with competencies that fit the current reality. Hence, the vision presented in this study seeks to provide guidance on the characteristics required by training programs for future education professionals.

\section{Conclusions}

The current state of education programs in Ecuador is ready for transformations. The Higher Education System needs rethinking and redesigns of the academic offerings to respond to trends in education. Theory must be applied to practice. There must be strong development of formative and scientific research, broader topical coverage and better quality of educational programs' offerings. Universities and educational science programs are central to the formation of individuals and the development of the country. The transformations must occur in four major areas: research, education, management and governance and social leadership. The fundamental competencies for education professionals, then, are innovation, research, entrepreneurship and digital transformation.

The data showed that the future vision of educational programs in Ecuador (and, perhaps, Ibero-America) is conditioned by the innovative offerings that educational institutions provide. The new offerings must allow students to perform in an increasingly competitive work world. To ensure their competitiveness, universities must implement new teaching-learning strategies that incorporate emerging technology, educational innovation, active learning methodologies and soft skills. Covid-19 changed the mode of study. The digital increasingly occupies relevant space among young people. To this, we must add the issue of flexibility in the curricula.

The students surveyed confirmed the study results: education programs have a future as long as the offerings are transformed. Among the most desired competencies in educational programs mentioned by the students are critical and creative thinking, innovative entrepreneurship, problem-solving and adaptation to difficulties. Therefore, teachers must be competent in organizational skills and pedagogy, deliver timely and highquality information and analyze diagnostics. In this work, the experts who participated in the research contributed ideas and concepts for the teachers' and students' successful adaptation to the information and educational environment. They filled gaps in new knowledge areas, successfully proposed resolutions of emerging professional issues and suggested the quality of training for their current environments and fuller implementation in professional activities. Therefore, the role of the teacher must transform; it cannot remain the same. The teacher will have to share the stage with artificial intelligence systems and understand Big Data, the Internet of Things and other technologies applicable to education. Consequently, classes can no longer be taught in the same way. The teacher cannot be a 
simple transmitter of knowledge. He or she be a mediator, a facilitator and a companion in the student's training process.

This study was delimited to trends in education programs. However, the data may be of interest to other disciplines, curriculum developers in different specialties, decisionmakers, academicians, researchers, students and social organizations interested in education. For future research, it is suggested to integrate different elements identified in this study within the framework of educational programs and develop an educational model contextualized to other countries and the training needs of educational professionals, considering the competencies demanded in today's society.

Author Contributions: Conceptualization, M.S.R.-M. and D.R.-R.; methodology, M.S.R.-M., D.R.R. and M.P.-C.; validation, L.A.-V., D.R.-R. and M.S.R.-M.; formal analysis, L.A.-V. and M.P.-C.; investigation, M.S.R.-M., D.R.-R., M.P.-C. and L.A.-V.; writing-original draft preparation, M.P.-C. and L.A.-V.; writing-review and editing, M.S.R.-M. and D.R.-R.; supervision, M.S.R.-M.; funding acquisition, D.R.-R. All authors have read and agreed to the published version of the manuscript.

Funding: This study was supported by the Rector's Office of the Universidad Técnica Particular de Loja (Ecuador) through its Vice Rector's Offices for Innovation and Distance Education. The project was developed in collaboration with Tecnologico de Monterrey (Mexico).

Data Availability Statement: Not applicable.

Acknowledgments: The authors acknowledge the technical and financial support of Writing Lab, Institute for the Future of Education, Tecnologico de Monterrey, Mexico, in the production of this work.

Conflicts of Interest: The authors declare no conflict of interest.

\section{References}

1. Hernández, R. Impact of ICT in education: Challenges and Perspectives. Propósitos y Represent. 2017, 1, 325-347. [CrossRef]

2. Vivas Urías, M.; Andrés Ortega, S.; Gómez Navarro, M. Development of digital competences in online teaching: The subject Foundations of the course of adaptation to degree in building engineering. Rev. Educ. Distancia (RED) 2016, 49. Available online: https:/ / revistas.um.es/red/article/view/257551 (accessed on 15 May 2021).

3. Abuhmaid, A. Teachers' Perceptions on the Impact of Flipped Learning on Student Learning and Teacher's Role in Jordanian Schools. Univers. J. Educ. Res. 2020, 8, 1007-1016. [CrossRef]

4. Faucher, K.X. Social Capital Online: Alienation and Accumulation; University of Westminster Press: London, UK, 2018. [CrossRef]

5. Horizon Report, Higher Education Edition. 2017. Available online: https:/ / eric.ed.gov/?id=ED582134 (accessed on 15 May 2021).

6. Talbert, E.; Hofkens, T.; Wang, M.-T. Does student-centered instruction engage students differently? The moderation effect of student ethnicity. J. Educ. Res. 2019, 112, 327-341. [CrossRef]

7. Keengwe, J.; Kidd, T.T. Towards Best Practices in Online Learning and Teaching in Higher Education. J. Online Learn. Teach. 2010, 6. [CrossRef]

8. Quintana, C. College Closings: More than 100 Colleges Cancel in-Person Classes and Move Online. 2020. Available online: https:/ / cutt.ly/RjAmP1d (accessed on 15 May 2021).

9. European Communities. Key Competences for Lifelong Learning-A European Framework. 2006. Available online: https: / / eur-lex.europa.eu/legal-content/ES/TXT/PDF/?uri=CELEX:32006H0962\&from=EN (accessed on 15 May 2021).

10. Bossolasco, M.L.; Chiecher, A.C.; Dos Santos, D.A. ICT access and appropriation profiles in university entrants. A comparative study in two Argentine public universities. Pixel-Bit J. Media Educ. 2020, 57, 151-172. [CrossRef]

11. Fedorov, A. Media and Information Literacy Education Dictionary; Scholars' Press: Moscow, Russia, 2017.

12. Markova, S.M.; Sedykh, E.P.; Tsyplakova, S.A.; Polunin, V.Y. Perspective trends of development of professional pedagogics as a science. Adv. Intell. Syst. Comput. 2018, 622, 129-135.

13. El comercio. 37 Centers in Ecuador Offer 286 Programs for Educators. 2018. Available online: https://acortar.link/h5mIV (accessed on 21 January 2021).

14. Fabara, E. Estado del Arte de la Formación Docente en el Ecuador; Cuadernos del Contrato Social por la Educación: Quito, Ecuador, 2013.

15. Ministry of Education. Agreement No.MINEDUC-ME-2015-00069-A, 1 April 2015. Available online: https:/ / educacion.gob.ec/ wp-content/uploads/downloads/2015/04/MINEDUC-ME-2015-00069-A.pdf (accessed on 15 May 2021).

16. Weigel, J.; Alegria, R. Managing the Future: Visions and Practices of the Global Foresight; Futurismo-Perspektiva: Brasil, 2018.

17. Coolhunting-ICEMD. Trends in Education; Coolhunting-Instituto Economía digital (ICEMD): Madrid, Spain, 2018.

18. Gaebel, M.; Zhang, T. Trends 2018: Learning and Teaching in the European Higher Education Area; European University Association asbl: Geneva, Switzerland, 2018. 
19. Ramírez-Montoya, M.S.; Loaiza-Aguirre, M.I.; Zúñiga-Ojeda, A.; Portuguez-Castro, M. Characterization of the Teaching Profile within the Framework of Education 4.0. Future Internet 2021, 13, 91. [CrossRef]

20. VVAA. Proposal of the Educational Community as Input for the New Ten-Year Education Plan 2016-2025. Available online: https: / / cutt.ly / bj7c073 (accessed on 21 January 2021).

21. Learning. For Life. Annual Report and Accounts 2020. Available online: https://plc.pearson.com/sites/pearson-corp/files/ annual-reports/Pearson_AR20_Online_210426.pdf (accessed on 15 May 2021).

22. Westbury, I.; Hansén, S.E.; Kansanen, P.; Björkvist, O. Teacher education for research-based practice in expanded roles: Finland's experience. Scand. J. Educ. Res. 2005, 49, 475-485. [CrossRef]

23. Sachs, J. Teacher professionalism: Why are we still talking about it? Teach. Teach. Theory Pract. 2016, 22, 413-425. [CrossRef]

24. Senplades, National Development Plan 2017-2021, A Whole Life. Available online: https://www.todaunavida.gob.ec/ (accessed on 15 May 2021).

25. Senescyt. Agreement N.2013-160. 2013. Available online: https://www.educacionsuperior.gob.ec/wp-content/uploads/ downloads / 2014/07 / Acuerdo-160-2013-Carreras-de-interes-publico.pdf (accessed on 15 May 2021).

26. UNESCO. Teacher Policy Development in Latin America and the Caribbean. Regional Bureau for Education in Latin America and the Caribbean (OREALC); UNESCO: Santiago, Chile, 2013.

27. Bocconi, S.; Kampylis, P.G.; Punie, Y. Innovating Learning: Key Elements for Developing Creative Classrooms in Europe; European Commission-Joint Research Centre-Institute for Prospective Technological Studies: Seville, Spain, 2012.

28. Bowen, W.G. Higher Education in the Digital Age; Princeton University Press: Princeton, NJ, USA, 2013.

29. Adams Becker, S.; Cummins, M.; Davis, A.; Freeman, A.; Hall Giesinger, C.; Ananthanarayanan, V. NMC Horizon Report: 2017 Higher Education Edition; The New Media Consortium: Austin, TX, USA, 2017.

30. Barnett, R. Conditions of Flexibility: Securing a More Responsive Higher Education System; The Higher Education Academy: York, UK, 2014.

31. NMER. Teacher Education 2025: National Strategy for Quality and Cooperation in Teacher Education; Norwegian Government Security and Service Organisation: Oslo, Norway, 2018.

32. Kochan, T.A.; Dyer, L. Shaping the Future of Work: A Handbook for Action and a New Social Contract; MITx Press: Cambridge, MA, USA, 2017.

33. Bucklin, B.A.; Asdigian, N.L.; Hawkins, J.L.; Klein, U. Making it stick: Use of active learning strategies in continuing medical education. BMC Med Educ. 2021, 21. [CrossRef] [PubMed]

34. Bermejo Díaz, J.M.; Salas, D.P.; Galmes-Panades, A.M.; Payeras, P.S.; Conti, J.V.; Verdaguer, F.J. Physical education and university: Evaluation of a teaching experience through cooperative learning. Retos 2021, 90-97. [CrossRef]

35. Giles Girela, F.J.; García, E.R.; Cervantes, C.T. University students' classroom management in a proposal of service learning in physical education in learning communities. Retos 2021, 224-230. [CrossRef]

36. Espejo-Garcés, T.; Cachón-Zagalaz, J.; Zurita-Ortega, F.; González-Valero, G.; Ubago-Jiménez, J.L. Study of psychosocial and academic indicators in young adults from Andalucía, Spain. Int. J. Environ. Res. Public Health 2021, 18, 363. [CrossRef] [PubMed]

37. Ferro, E.F.; Ruiz, N.E.; Rojas, P.J.; Cid, F.M.; Gutiérrez Duarte, S.A.; Begazo, S.C.; Magallanes, V.D. Analysis of the graduate profile of Chile's physical education pedagogy degree: A quantitative study. Retos 2021, 532-538. [CrossRef]

38. Ciesielkiewicz, M.; Bonilla, C.F.; Santos Peñas, M. The Acquisition of Competences in Transnational Education through the ePortfolio; Springer: Cham, Switzerland, 2021. [CrossRef]

39. Ferrero-de-Lucas, E.; Cantón-Mayo, I.; Menéndez-Fernández, M.; Escapa-González, A.; Bernardo-Sánchez, A. ICT and knowledge management in teacher training and engineering students. Comunicar 2021, 29, 57-67. [CrossRef]

40. López, T.I.S.; Nardi, R. Imaginary of future physics teachers about teaching knowledge: Senses produced in the university-school interface in the supervised curricular internship. Investig. Em Ensino Cienc. 2021, 25, 454-470. [CrossRef]

41. Yin, R. Case Study Research and Applications: Design and Methods; Sage Publications: Los Angeles, CA, USA, 2017.

42. Creswell, J.W.; Poth, C.N. Qualitative Inquiry and Research Design: Choosing among Five Approaches; Saga Publications: Thousand Oaks, CA, USA, 2018.

43. Yin, R. Applications of Case Study Research, Applied Social Research Methods Series; Sage Publications: Newbury Park, CA, USA, 2012.

44. Díaz-Barriga, F.; Lule González, M.; Pacheco Pinzón, D.; Saad Dayaán, E.; Rojas Drummond, S. Methodology of Curriculum Design for Higher Education; Trillas: Coahuila, Mexico, 1998.

45. Cárdenas, C. Benchmarking as an evaluation tool. Acimed 2005, 14. Available online: http://scielo.sld.cu/scielo.php?script=sci_ arttext\&pid=S1024-94352006000400015 (accessed on 15 May 2021).

46. Ramírez-Montoya, M.S. Obsolescencia del conocimiento vs formación para el desarrollo sostenible: Voces de protagonistas en el marco del COVID 19. Texto Livre Ling. Tecnol. 2021. In Press. 